\title{
What Do We Reliably Know about European Perceptions of Muslim Asylum Seekers?
}

\author{
Louis Talay \\ University of Sydney \\ louis.talay2001@outlook.com
}

\begin{abstract}
Immigration restrictions imposed by national governments are arguably the factor most responsible for the European Refugee Crisis (ERC). As immigration policies do not fall under the remit of European Union sovereignty, the union's democratic nations are free to operate their own regimes. Although the primary drivers of national immigration policies have been identified as both economic and cultural in nature, empirical evidence suggests that the latter is of greater significance. Given that the perceived fear of value incompatibilities forms the basis of all cultural arguments against immigration, it was necessary to investigate the accuracy of perceptions of Muslim Asylum Seeker Values (MASV) by administering surveys in two countries at the opposite end of the immigration policy spectrum: Hungary and the Netherlands. Hungarians significantly overestimated MASV extremity while Dutch people underestimated them. Moreover, the results indicated that perceptions of MASV extremity correlate with immigration policy preferences.
\end{abstract}

Keywords: Europe, Refugee Crisis, Immigration Policy, Xenophobia, Perceptions of Muslim Refugees

\section{Introduction}

The European Refugee Crisis (ERC) has emerged as an indirect result of the Syrian war and general conflict in the Middle East that has put the lives of civilians in that region in serious danger. Although there is no disputing that this very source of the ERC needs to be attended to through the development of a sustainable geopolitical strategy, such efforts cannot come at the expense of the immediate lives of those that have been forced to leave that region to protect themselves and their families. The term, 'crisis' refers to both the situation of the refugees and to the response of the Europeans. Indeed, we can identify the direct cause of the ERC in the immigration limitations imposed by European host countries. If Europe simply allowed every asylum seeker to settle in its territory the ERC wouldn't be a 'crisis.' Although such a scenario is completely unrealistic, understanding the premise may enable us to establish an effective departure point for a sustainable solution. In the current situation, the majority of EU countries exist at the opposite end of the policy spectrum, operating restrictive and ad hoc immigration regimes. ${ }^{1}$

\footnotetext{
${ }^{1}$ Bjerre, L, Helbling, M., Römer, F., Zobel, M. (2016) 'The Immigration Policies in Comparison (IMPIC) Dataset: Technical Report, Berlin Social Science Center
} 
As immigration policy remains a national competence within the EU, the decision as to how many Muslim Asylum Seekers (MAS) are permitted to settle in a given country is made by that country alone. Moreover, because strict democratic electoral procedures are a requirement for EU accession, it can be deduced that the public's perception of foreigners in a given country of the EU plays a major role in determining that nation's immigration policy. Studies have demonstrated that locals are most concerned with the values held by foreigners settling or attempting to settle in their country. ${ }^{2}$ As MAS constitute a considerable proportion of foreigners in the public's eye, ${ }^{3}$ I hypothesise that European perceptions of the values held by MAS (MASV) will correlate with immigration policy preferences. Ultimately, this paper seeks to achieve three objectives, namely to:

1. assess how important European perceptions of MASV are in determining national immigration policy.

2. measure how inaccurate these perceptions are.

3. identify potential causes of this inaccuracy.

Several prominent theories suggest explanatory models for immigration policy influences through both economic and cultural factors. These will be explored in the next section of the paper. Moreover, much has been said about the rise of right-wing nationalism throughout Europe in recent times, and how the media has played an important role in the ascension of these parties. Section three will review the literature on both of those topics. In the conclusion to this section I aim to have ascertained what one can reliably conclude regarding the main determinants of attitudes toward immigration. Considering the scarce literature available on the ways in which Europeans perceive MASV and the accuracy of these perceptions, I will field a values survey in The Netherlands and Hungary to test my hypothesis. The methodology will be outlined in section four and the results will be presented. The final section of the paper will discuss these results and provide recommendations for future research in the field of immigration attitudes.

Funding restrictions limited this study to two countries, and the selection was based on the desire to represent two countries existing at opposite ends of the immigration policy spectrum.

\footnotetext{
${ }_{2}^{2}$ Sides, J., Citrin, J. (2007) 'European Opinion About Immigration: The Role of Identities, Interests and Information,' British Journal of Political Science, Vol. 37, Issue 3, pp. 477-504; Lucassen, G., Lubbers, M. (2012) 'Who Fears What? Explaining Far-Right-Wing Preference in Europe by Distinguishing Perceived Cultural and Economic Ethnic Threats,' Comparative Political Studies, Vol. 45, Issue 5; Sniderman, P., Hagendoorn, L. (2007) When Ways of Life Collide: Multiculturalism and Its Discontents in the Netherlands. Princeton: Princeton University Press; Markaki, Y., Longhi, S. (2013) 'What determines attitudes to immigration in European countries? An analysis at the regional level,' Migration Studies, Vol. 1, Issue 3.

3 Ipsos MORI (2016) 'Perceptions are not reality: what the world gets wrong,' Ipsos MORI: Game Changers, viewed from https://www.ipsos.com/ipsos-mori/en-uk/perceptions-are-not-reality-what-world-gets-wrong
} 


\section{Social Theories}

Immigrant policy literature has grown considerably since the outbreak of the ERC. A range of theories and conclusions have been used to explain the origins of intercultural fears and anti immigration sentiments. These models can be divided into two categories: economic and non-economic arguments.

\section{i. Economic arguments}

Fundamentally, arguments grounded in economics hold that immigration policy preferences are largely dependent upon the strength of the national economy. Accordingly, whenever an economy is prospering, immigration is likely to be supported, and conversely during a tangible contraction phase will be denounced. Within this category there are two prominent theories; labour market competition theory (LMCT) and fiscal burden theory (FBT). Commencing with the former, Scheve and Slaughter affirmed that lower-skilled workers in the US were far more likely to resent immigration because the vast majority of migrants would have professional and educational profiles similar to their own and consequently represent a threat to the former's employment. ${ }^{4}$ Likewise, Borjas et al designed a factor proportions analysis, which views immigrants as an addition to the labour supply of a given sector, rendering them unpopular with natives whenever that supply becomes unsupportable. ${ }^{5}$ Mayda echoes this sentiment, demonstrating in a cross-national study that attitudes toward an influx of immigrants are contingent upon the average difference in skill level between both natives and immigrants. ${ }^{6}$ Another study concluded that immigration preferences were contingent upon the level of growth within one's sector of employment. ${ }^{7}$ Survey data from multiple European countries between 2002 and 2009 indicated that local workers were indifferent to immigration whenever their economic sector was expanding, however when growth stalled and the sector declined, the level of support significantly diminished.

As is the case with LMCT, there are various accounts of the FBT. Hanson claims that although most American citizens are aware of the long term economic benefits associated with immigration, they realise the public budget is limited. ${ }^{8}$ Another study showed that the distribution of public finances correlated with attitudes towards immigrants and not with national trade policy, as is often argued. ${ }^{9}$ It was suggested that this might be why the US immigration policy was a lot more liberal at the start of the twentieth century, as welfare spending was virtually non-existent. ${ }^{10}$ Facchini and Mayda offered a more nuanced explanation of FBT,

\footnotetext{
${ }_{4}$ Scheve, K., Slaughter, M. (2001) 'Labour Market Competition and Individual Preferences Over Immigration Policy,' The Review of Economics and Statistics, Vol. 83, Issue 1.

5 Borjas, G., Freeman, R., Katz, L. (1996) 'Searching for the Effect of Immigration on the Labor Market,' NBER Working Paper No. 5454, NBER Program.

${ }^{6}$ Mayda, A.M. (2006) 'Who is against immigration? A cross-country investigation of individual attitudes toward immigrants,' Review of Economics and Statistics, Vol. 88, Issue 3.

7 Dancygier, R., Donnelly, M.J. (2012) 'Sectoral Economies, Economic Contexts, and attitudes toward Immigration,' The Journal of Politics, Vol 75, Issue 1, pp. 17-35

${ }^{8}$ Hanson, G. (2005) Why Does Immigration Divide America? Washington, DC: Institute for International Economics.

${ }_{9}$ Hanson, G., Scheve, K., Slaughter, M. (2007) 'Public Finance and Individual Preferences over Globalisation

Strategies.' Economics and Politics, Vol. 19, Issue 1, pp. 1-33.

1o Ibid.
} 
high income individuals are worse hit by unskilled immigration only if taxes are raised to maintain per capita transfers... agents at the bottom of the income distribution will suffer more with unskilled immigration if tax rates are kept constant and the adjustment is carried out through a reduction in the per capita transfers. These relationships are reversed in the case of skilled migration. ${ }^{11}$

Hainmueller and Hiscox set up several experiments to test whether either the LMCT or FBT could be supported by empirical evidence. ${ }^{12}$ Their findings were 'at odds with the claim that concerns about labour market competition are a driving force in shaping attitudes toward immigration'.$^{13}$ On the contrary, they demonstrated the statistical link between education levels and immigration preferences. On the whole, natives preferred high skilled immigrants to low skilled immigrants. In testing the FBT, the authors discovered that, 'in high-fiscal exposure states the premium attached to highly skilled immigration relative to low skilled immigration is decreasing in respondents' income level. ${ }^{14}$

This would appear to refute a basic premise of the FBT. Likewise, Markaki and Longhi were able to prove that lower qualifications among both natives and immigrants were associated with lower perceptions of economic threat from immigration..$^{15}$ Although previous studies were able to find a positive correlation between economic variables and immigration preferences through different experimental methods, ${ }^{16}$ there are enough findings to cast suspicions on the validity of LMCT and FBT in predicting attitudes to immigration (Hainmueller \& Hiscox, 2010; Lucassen \& Lubbers, 2011; Sniderman \& Hagendoorn, 2007; Muddle, 2007; Markaki \& Longhi, 2013). ${ }^{17}$

\section{ii. Non-economic arguments}

While global immigration levels have been on the rise since the end of the Second World War, every country has had its own unique set of experiences with immigrants from different cultures. Several social theorists have attempted to explain why a diverse spectrum of multicultural attitudes has emerged.

Since the mid 1950s, scholars have theorised and attempted to prove that increased contact with foreign cultures correlates with diminished intergroup conflict. Gordon Allport was the father of what is known as Intergroup Contact theory, which has been the foundation of countless social reconciliation policies throughout the world. ${ }^{18}$ The

\footnotetext{
${ }^{11}$ Facchini, G., Mayda, A. (2009) 'Does the Welfares State Affect Individual Attitudes toward Immigrants? Evidence across Countries.' Review of Economics and Statistics, Vol. 91, Issue 2, p. 312

${ }^{12}$ Hainmueller, J., Hiscox, M. (2010) 'Attitudes toward Highly Skilled and Low-skilled Immigration: Evidence from a Survey Experiment,' American Political Science Review, Vol. 104, Issue 1

${ }_{13}$ Ibid, p. 68

${ }_{14}$ Ibid, p. 81

${ }^{15}$ Markaki, Y., Longhi, S. 'What determines attitudes to immigration in European countries? An analysis at the regional level.'

${ }^{16}$ Scheve \& Slaughter, 'Labour Market Competition and Individual Preferences Over Immigration Policy'; Mayda, 'Who is against immigration? A cross-country investigation of individual attitudes toward immigrants'; Facchini, G., Mayda, A. (2009) 'Does the Welfares State Affect Individual Attitudes toward Immigrants? Evidence across Countries.' Review of Economics and Statistics Vol. 91, Issue 2, pp. 295-314

${ }^{17}$ Hainmueller \& Hiscox. 'Attitudes toward Highly Skilled and Low-skilled Immigration: Evidence from a Survey Experiment'; Lucassen \& Lubbers, 'Who Fears What? Explaining Far-Right-Wing Preference in Europe by Distinguishing Perceived Cultural and Economic Ethnic Threats,'; Sniderman \& Hagendoorn, When Ways of Life Collide: Multiculturalism and Its Discontents in the Netherlands; Muddle, C. (2007) Populist radical right parties in Europe. Cambridge, UK: Cambridge University Press; Markaki \& Longhi, 'What determines attitudes to immigration in European countries? An analysis at the regional level'

${ }_{18}$ Allport, G. (1954) The Nature of Prejudice. Cambridge/Reading, MA: Addison-Wesley.
} 
author stipulated that four conditions needed to be met in order for intergroup contact to generate a positive response regarding immigration attitudes. Those conditions are: equal status among immigrants and locals, co-operation between groups, common goals and support by social and institutional authorities. However, two large-scale analyses have since then demonstrated these conditions merely facilitate proceedings and aren't even necessary for achieving a reduced level of prejudice. ${ }^{19}$ Self reported prejudices are the most common way of proving the theory's validity, ${ }^{20}$ yet other studies have demonstrated a positive change in physiological responses ${ }^{21}$ and subconscious biases. ${ }^{22}$ Pettigrew argues that the positive effect can be attributed to a combination of four processes: learning about the out-group, changing one's behaviour through intermingling, generating affective ties with the out-group, and finally ingroup reappraisal. $^{23}$

At the opposite end of the theoretical spectrum lies Ethnic Competition theory, which posits that natives will hold antagonistic views of immigrants whenever both groups hold similar qualifications and immigration levels increase. Although this would appear strikingly similar to LMCT, Scheepers, Gijsberts and Coenders make the important distinction between individual and contextual competitive conditions that explains the difference between the two theories. ${ }^{24}$ Individual competitive conditions refer exclusively to one's position in the labour market and are thus the defining factor of LMCT. On the other hand, contextual competitive conditions measure the relationship between the proportion of non-EU citizens in a given EU population and the perceived ethnic threat. Several authors have emphasized the importance of this factor in intercultural conflict. ${ }^{25}$ Other scholars have argued that this effect is more pronounced among lower skilled and lower educated groups, which would normally suggest that economic conditions were more determinant of anti immigration sentiments. ${ }^{26}$ However, in both of the latter cases data was taken during economic crises, which doesn't allow for an accurate reflection of common individual attitudes.

\footnotetext{
${ }_{19}$ Pettigrew, T., Tropp, L. (2006) 'A meta-analytic test of intergroup contact theory, Journal of Personality and Social Psychology, Vol. 90, Issue 5; Al Ramiah, A., Hewstone, M., Schmitt, K. (2011) Intergroup difference and harmony: The role of intergroup contact. In Singh, P., Bain, P., Leong, C., Misra, G., Ohtsubo, Y. (Eds.), Individual, group and cultural processes in changing societies. Progress in Asian Social Psychology (Series 8), pp. 3-22. Delhi: University Press.

${ }^{20}$ Vonofakou, C., Hewstone, M., Voci, A. (2007) 'Contact with outgroup friends as a predictor of meta-attitudinal strength and accessibility of attitudes towards gay men.' Journal of Personality and Social Psychology, Vol. 92, pp. 804-820; Caspi, A. (1984) 'Contact Hypothesis and Inter-Age Attitudes: A Field Study of Cross Age Contact,' Social Psychology Quarterly, Vol. 47, Issue 1

${ }^{21}$ Blascovich, J., Mendes, W., Hunter, S., Lickel, B., Kowai-Bell, N. (2001) 'Perceiver threat in social interactions with stigmatized others,' Journal of Personality and Social Psychology, Vol. 8o, pp. 253-267

${ }^{22}$ Aberson, C., Haag, S. (2007) Contact, perspective taking, and anxiety as predictors of stereotype endorsement, explicit attitudes, and implicit attitudes. Group Processes and Intergroup Relations, Vol. 10, pp. 179-201.

${ }_{23}$ Pettigrew, T. (1998) 'Intergroup contact theory,' Annual review of psychology, Vol. 49, issue 1, pp. 65-85.

${ }^{24}$ Scheepers, P., Gijsberts, M., Coenders, M. (2002) 'Ethnic exclusionism in European countries. Public opposition to civil rights for legal migrants as a response to perceived ethnic threat,' European Sociological Review Vol. 18, pp. 17-34

${ }_{25}$ Schlueter, E., Scheepers, P. (2010) 'The relationship between outgroup size and anti-outgroup attitudes: A theoretical synthesis and empirical test of group threat- and intergroup contact theory,' Social Science Research Vol. 39: pp. 285-95; Schneider, S. (2008) 'Anti-immigrant attitudes in Europe: Outgroup size and perceived ethnic threat,' European Sociological Review 24: pp. 53-67; Quillian, L. (1995) 'Prejudice as a response to perceived group threat: Population composition and anti-immigrant and racial prejudice in Europe,' American Sociology Review Vol. 60: 586-611; Blalock, H. (1967) Toward a Theory of Minority Group Relations, New York: John Wiley \& Sons.

${ }^{26}$ Olzak, S. (1994) The Dynamics of Ethnic Competition and Conflict, Stanford, CA: Stanford University Press; Van Setten, M., Scheepers, P., Lubbers, M. (2017) 'Support for restrictive immigration policies in the European Union 2002-2013: the impact of economic strain and ethnic threat for vulnerable economic groups, European Societies, Vol. 19, Issue 4, pp. 440-465.
} 
Neither Intergroup Contact theory, nor Ethnic Competition theory is supported by reliable empirical data. As mentioned earlier, although there was some evidence to suggest that economic variables influence immigration policy preferences, these results appeared to hinge on the study's methodology. Moreover, various scholars maintain that economic fears were significantly mitigated wherever post-secondary education was attained. ${ }^{27}$ Several studies were able to able to conclude that perceived cultural threats were stronger predictors of immigration preferences than are perceived economic threats. ${ }^{28}$ Similarly, Koning demonstrated in an extensive crossnational study that although concerns of welfare abuse may play a role in anti immigration sentiment, it is the 'political translation' of those facts that holds greater sway. ${ }^{29}$ Despite not being able to present empirical evidence to support their restrictive policies, right wing political parties such as the PVV in the Netherlands will convince a considerable portion of the public that they possess the 'facts' to substantiate their agenda. Moreover, the author argued that persuading the public to tolerate immigration policy changes was substantially easier than in other fields of social policy. As he put it,

Few voters will themselves be affected by policy changes aimed at disentitling future newcomers to the country... Instead of democratic opposition, a more significant obstacle to exclusionary welfare reforms is posed by prohibitions on differential treatment flowing from both domestic and international legal structures' 30

The ease at which this is achieved has enabled populist right wing rhetoric to use false, sensationalist claims to influence public opinion about the cultural threat of immigration.

As stated in the introduction, a potentially major obstacle to the consequences of the anti-immigration framing in the EU has not been accounted for in the form of European legislation. Consequently, politicians of member states have exercised their capacities as 'identity entrepreneurs' and built their campaigning strategies around notions of what their target group represents. ${ }^{31}$ Mols and Jetten discovered that evoking a deep sense of nostalgia is often the key feature of populist right-wing party attempts to shape opinion. ${ }^{32}$ These groups commonly disperse narratives that extol the past and blame the decline of the present on its disconnection from old customs and certainties. One study has proven that nostalgic longing for the past is considerably

\footnotetext{
${ }_{27}$ Hainmueller, J., Hiscox, M. (2007) Educated Preferences: Explaining Attitudes toward immigration in Europe. International Migration Review, Vol. 30, No. 2; Bilodeau, A., Fadol, N. (2011) 'The roots of contemporary attitudes toward immigration in Australia: contextual and individual-level influences,' Ethnic and Racial Studies, Vol.34, Issue 6; Cavaille, C., Marhsall, J. (2017) 'Education and Anti-Immigration Attitudes: Evidence from Compulsory Schooling Reforms Across Western Europe,' Harvard University, viewed from https://scholar.harvard.edu/files/jmarshall/files/education_and_anti-immigration_attitudes_o.pdf

${ }^{28}$ Sides \& Citrin, 'European Opinion About Immigration: The Role of Identities, Interests and Information'; Lucassen \& Lubbers, 'Who Fears What? Explaining Far-Right-Wing Preference in Europe by Distinguishing Perceived Cultural and Economic Ethnic Threats,'; Sniderman \& Hagendoorn, When Ways of Life Collide: Multiculturalism and Its Discontents in the Netherlands; Markaki \& Longhi, 'What determines attitudes to immigration in European countries? An analysis at the regional level'

29 Koning, E. (2013) 'Selective Solidarity: The politics of immigrants' social rights in Western welfare states,' (Doctoral dissertation). Kingston, Ontario, Canada: Retrieved from Queen's University.

$3^{\circ}$ Ibid, p270

${ }^{31}$ Reicher, S., Hopkins, N. (2001) Self and Nation, Sage, London, UK.

${ }^{32}$ Mols, F., Jetten, J. (2014) 'No guts, no glory: How framing the collective past paves the way for anti-immigrant sentiments,' International Journal of Intercultural Relations, Vol. 43, Part A.
} 
more powerful when continuity has been interrupted. ${ }^{33}$ So if a country such as Hungary - that has historically experienced low levels of immigration - were all of a sudden to be faced with hundreds of thousands of asylum seekers at their borders, nostalgic narratives would be likely to impact a significant proportion of voters.

Furthermore, empirical data indicates that ethnocentric rhetoric isn't simply an esoteric tool deployed by fringe, right-wing radical parties, but in fact rather regularly influences the agenda of centre-right parties, a situation that has consequences for the entire political spectrum. ${ }^{34}$ So if a far-right party is able to frame its anti-immigration proposal around a series of pseudo-facts, centre-right agendas will adapt out of the fear of losing voters to their more radical contemporaries. Dekker \& Scholten demonstrate how it only takes a small-scale incident to galvanise the public's sensibilities toward controversial stances on large-scale policy issues. ${ }^{35}$ The authors discovered that policy agendas are often adapted when media framing of isolated cases contests the agenda of the incumbent government. Moreover, much of the media has consistently portrayed MAS in a negative light across several EU countries and given biased accounts of Muslim-led violence in comparison to non-Muslim incidents. ${ }^{36}$ So if rightwing populism is able to overplay small-scale events and conjure up nostalgic narratives that galvanise anti-immigration attitudes, what do these narratives look like?

The term 'solidarity' permeates the literature, and is commonly viewed as the key mechanism for engendering a sense of nationhood. ${ }^{37}$ At a basic level, the concept refers to an individual's sense of belonging to a larger group based on shared qualities or characteristics. It is the defining feature of Social Identity theory, which states that an individual's idea of who they are is primarily based on what groups they identify with. ${ }^{38}$ Moreover, to enhance their social status, individuals look to positively differentiate their own group from other groups in society, creating a contest between in-groups and out-groups. Kymlicka argues that the onset of social projects in the post war era lead to a 'progressives dilemma' where nations believed they had to make a decision between solidarity and diversity. ${ }^{39}$ This arises from the belief that a multicultural society suffers from weaker conceptions of solidarity, as outsiders would have legal

\footnotetext{
33 Iyer, A., Jetten, J. (2011) 'What's left behind: Identity continuity moderates the effect of nostalgia on well-being and life choices,' Journal of Personality and Social Psychology, Vol.101, Issue 1.

${ }_{34}$ Mols, F. (2012) What makes a frame persuasive? Lessons from social identity theory. Evidence \& Policy, Vol. 8, Issue 3, pp. 329-345.

${ }_{35}$ Dekker, R., Scholten, P. (2017) 'Framing the Immigration Policy Agenda: A Qualitative Comparative Analysis of Media Effects on Dutch Immigration Policies,' The International Journal of Press/Politics, Vol. 22, Issue 2.

${ }_{36}$ Berry, M., Garcia-Blanco, I., Moore, K. (2015) 'Press coverage of the Refugee and Migrant Crisis in the EU: A Content Analysis of Five European Countries,' Report prepared for the United Nations High Commission for Refugees, Cardiff School of Journalism, Media and Cultural Studies; West, K., Lloyd, J. (2017) 'The Role of Labelling and Bias in the Portrayals of Acts of 'Terrorism': Media Representations of Muslims vs Non-Muslims,' Journal of Muslim Minority Affairs, Vol. 37, Issue 2, pp. 211-222; Jacobs, L., Meeusen, C., D'haenens, L. (2016) 'News coverage and attitudes on immigration,' European Journal of Communication, Vol.3, Issue 6, pp. 642-66o. ${ }_{37}$ Calhoun, C. (2002) 'Imagining Solidarity: Cosmopolitanism, Constituional Patriotism, and the Public Sphere.' Public Culture, Volume 14, Issue 1; Sager, A. (2016) 'Methodological Nationalism, Migration and Political Theory,' Political Studies, Vol. 64, Issue 1; Kymlicka, W. (2015) 'Solidarity in diverse societies: beyond neoliberal multiculturalism and welfare chauvinism. Comparative Migration Studies, Vol. 3, Issue 4, pp. 301-334. ${ }_{38}^{8}$ Tajfel, H., Turner, J. (1979) 'An integrative theory of intergroup conflict'. In W. Austin \& S. Worchel. The social psychology of intergroup relations. Monterey, CA: Brooks/Cole. pp. 33-47; Sniderman, P., Hagendoorn, L., Prior, M. (2004) 'Predisposing Factors and Situational Triggers: Exclusionary Reactions to Immigrant Minorites', The American Political Science Review, Vol. 98, No. 1; Huddy, L. (2001) 'From Social to Political Identity: A Critical Examination of Social Identity Theory', Political Psychology, Vol. 22, Issue 1; Brown, R. (2000) 'Social Identity Theory: Past Achievements, Current Problems and Future Challenges', European Journal of Social Psychology, Vol. 30, Issue 6, pp. 745-778.

${ }_{39}$ Kymlicka, 'Solidarity in diverse societies: beyond neoliberal multiculturalism and welfare chauvinism'
} 
access to the limited social membership services, fracturing the value-based unity the in-group previously enjoyed. The welfare state was conceived as a service for those who belonged to that society and not a tool for universal humanitarianism. However, multiple studies have proven that diversity and solidarity are not mutually exclusive concepts by demonstrating in cross-national studies that attitudes towards multiculturalism don't correlate with social spending. ${ }^{40}$

Finally, conceptions of solidarity need to be viewed from an ideological perspective in order to properly comprehend the way public opinion is shaped. Ring-wing populist parties construct national identity crisis narratives in order to improve their bargaining position in the electoral market. ${ }^{41}$ Yet while the parties' leaders perform the role of identity entrepreneur, they are also staunch protectors of liberal principles. Several scholars assert that the far right claims to resent immigration for the dangers it brings to the foundational elements of a liberal society such as gender equality and the separation of religion and the state. ${ }^{42}$ Subsequently, an identity is formed on the basis of an identifiable set of common values, which then generates an 'us versus them' mentality. ${ }^{43}$ Those who don't share the set of values held by the majority are considered as outsiders who don't belong to that society and therefore don't deserve access to its welfare system and labour market. This is because they are believed to have consciously chosen to identify with a group that is at odds with that society's core values. Symbolic Racism theory would hold that it is these conflicting sets of values that lead to racism. ${ }^{44}$

So in summary, while there is some evidence to suggest that economic fears of immigration affect individual policy preferences, cultural fears appear to be better determinants of the outcome. Several scholars present rational arguments that link these cultural apprehensions to the belief that the values held by immigrants are incompatible with those espoused in host countries. ${ }^{45}$ Moreover, as biased accounts of small-scale issues from the media and populist politicians appear to stimulate these fears, it would be interesting to discover how accurate public perceptions are of the values held by the group of immigrants causing the greatest stir in contemporary news. Subsequently, this paper will quantitatively measure the accuracy of European perceptions of Muslim Asylum Seeker Values (MASV). I hypothesise that both Hungarian and Dutch perceptions of MASV will significantly overestimate the

\footnotetext{
40 Brady, D., Finnigan, R. (2014) ‘Does Immigration Undermine Public Support for Social Policy,' American Sociological Review, Vol. 79, Issue 1; Kesler, C., Bloemraad, I. (2010) 'Does Immigration Erode Social Capital? The Conditional Effects of Immigratio-Generated Diversity on Trust, Membership, and Participation across 19 Countries, 1981-2000.' Canadian Journal of Political Science, Vol. 43, Issue 2, pp. 319-47; Banting, K., Kymlicka, W. (2006) Multiculturalism and the Welfare Stat: Recognition and Redistribution in Democracies. Oxford: Oxford University Press.

${ }^{41}$ Betz, H-G. (1993) 'The new politics of resentment: Radical right wing populist parties in Western Europe', Comparative Politics, Vol. 25, Issue 4; ${ }^{41}$ Swank, D., Betz, H-G. (2003) 'Globalization, the welfare state and right wing populism in Western Europe', Socio-Economic Review, Vol. 1, pp. 215-245

${ }_{42}$ Akkerman, T. (2005) 'Anti-Immigration parties and the defence of liberal values: The exceptional case of the List Pim Fortuyn,' Journal of Political Ideologies, Vol. 10, Issue 3; Ponce, A. (2017) ‘Gender and Anti-immigrant Attitudes in Europe,' Socius: Sociological Research in a Dynamic World, Vol. 3, pp. 1-17; Joppke, C. (2010) Citizenship and Immigration. Oxford: Polity; Tebble, A. (2006) 'Exclusion for democracy,' Political Theory, Vol. 34, Issue 4, pp. 463-87

${ }_{43}$ Schmitt, C. (1996) The Concept of the Political. Chicago: University of Chicago Press.

${ }^{4}$ Kinder, D., Sears, D. (1981) 'Prejudice and politics: Symbolic racism versus racial threats to the good life,' Personality and Social Psychology Review, Vol. 10, pp336-353; McConahay, J. (1982) 'Self-interest versus racial attitudes as correlates of anti-busing attitudes in Louisville: Is it the buses or the blacks?' Personality and Social Psychology Review, Vol. 10, pp. 336-353.

45 Akkerman, 'Anti-Immigration parties and the defence of liberal values: The exceptional case of the List Pim Fortuyn'; Ponce, 'Gender and Anti-immigrant Attitudes in Europe'; Joppke, C. (2010) Citizenship and Immigration; Tebble, A. (2006) 'Exclusion for democracy'
} 
extremity of MASV due to the negative bias in the media's portrayal of MAS. ${ }^{46}$ Additionally, I expect to see a correlation between perceptions of MASV extremity and several immigration preference variables. Finally, I anticipate discovering that low education levels will be a major cause of these inaccurately held perceptions.

\section{Methodology}

In order to assess the accuracy of these perceptions a common reference point needed to be established. Accordingly, a basket of progressive values (BPV) was created, containing seven potentially polarising issues and principles. The selection of these issues attempted to cover a mix of progressive principles that the majority of European societies support with violence based fears. Participants from the Netherlands $(\mathrm{N}=260$ and Hungary $(\mathrm{N}=252)$ were required indicate on a slider graph what percentage of MAS they thought would agree with the following statements:

1. A woman must always obey her husband.

2. Homosexuality is morally acceptable.

3. Abortion should be made illegal.

4. People should be free to choose their religion and practice it freely.

5. One can justify killing a family member if they have committed adultery or had non-marital sex.

6. Attacks on civilians are justifiable if they are in defence of Islam.

7. Authoritarian governments are better than democratic ones in times of difficulty.

Mean results would be calculated and mapped on a graph of perceived extremity of MASV. These would then be compared with Real MASV data obtained from the Pew Research Center. ${ }^{47}$ Given that this would require a mean score to be calculated from six MAS sender countries, one would have to account for population size. Subsequently, Real MASV scores were calculated through the application of the following formula:

$\left(C_{1} P / T A S \times\right.$ C1meanvalue $)+(C 2 P / T A S \times C 2 m e a n v a l u e)+\left(C_{3} P / T A S \times C 3 m e a n\right)$ etc >>> $C_{5}$ or C6 depending on the amount of countries with available data on each issue.

Where:

-C1P indicates the Asylum Seeker population in Europe of country number 1 in this study

-TAS refers to the combined Total Asylum Seeker population in Europe of all five or six MAS countries (depending on available data)

\footnotetext{
${ }^{46}$ West \& Lloyd, 'The Role of Labelling and Bias in the Portrayals of Acts of 'Terrorism': Media Representations of Muslims vs Non-Muslims'; Berry, Garcia-Blanco, \& Moore, 'Press coverage of the Refugee and Migrant Crisis in the EU: A Content Analysis of Five European Countries'; Jacobs, Meeusen \& D’haenens, 'News coverage and attitudes on immigration'

${ }_{47}$ Connor, P. (2016) "Number of Refugees to Europe surges to record 1.3 Million in 2015," Pew Research Center Global Attitudes and Trends; Hackett, C. (2016) “5 Facts about the Muslim Population in Europe,” Pew Research Center- Fact Tank; Bell, J., Lugo, L. (2013) 'The World’s Muslims: Religion, Politics and Society', Pew Research Center
} 
-C1meanvalue refers to the mean score obtained for country number 1 in response to the value under question.

$\mathrm{C}_{2} \mathrm{P}, \mathrm{C}_{3} \mathrm{P}, \mathrm{C}_{4} \mathrm{P}, \mathrm{C}_{5} \mathrm{P}$ and $\mathrm{C} 6 \mathrm{P}$ correspond with the other countries in the study, as do C2meanvalue, C3meanvalue etc.

Wherever MASV data is displayed on a graph with a scale that exceeds 100, total MASV or MASV perception scores were calculated by simply adding the results from each BPV question. As these are based on MASV extremity levels or perceptions thereof, inverse results were obtained for questions two and four given that they were positively formulated.

Participants were also asked what they thought their country's non-Muslim citizens views were on the exact same questions, with the wording of question six changing from 'Islam' to 'one's religion.' This was done in order to gain further understanding of the perceived level of compatibility between value sets. Furthermore, participants were required to state what their personal views were on all BPV issues.

Despite only fielding surveys in two European countries, I believe that one will be able to make a number of reasonable assumptions about the perceptions of MASV among other EU countries through an analysis of the survey's comparative variable data. This data will be obtained from individual responses to five questions pertaining to immigration preferences. Participants would provide this information prior to filling in the BPV sliders. The questions are (answer stems in brackets):

1. How important is the adoption of Dutch/Hungarian customs and traditions to becoming truly Dutch/Hungarian? (Very important, somewhat important, not really important, not important at all).

2. Growing diversity makes our country a better place to live? (Strongly agree, agree, neither agree nor disagree, disagree, strongly disagree)

3. Muslim Asylum Seekers want to adopt the Dutch/Hungarian way of life? (Strongly agree, agree, neither agree nor disagree, disagree, strongly disagree)

4. Indicate with which statement you agree most. (There are too many Muslims in NL/HUN, there is about the right amount of Muslims in NL/HUN, there aren't enough Muslims in NL/HUN, it doesn't matter how many Muslims there are in NL/HUN)

5. We should allow more Muslim Asylum Seekers to settle in our country. (Strongly agree, agree, neither agree nor disagree, disagree, strongly disagree).

As stated in my second hypothesis, I believe there will be a strong correlation (pearson's $r>0.15$ ) between these five comparative variables and perceptions of mean MASV extremity. Should this be the case then one will be able to make reasonable predictions about MASV perceptions in other European countries based on the comparable variable data.

\section{Results}

This section of the paper will present the public opinion data received from the surveys run in both Hungary and the Netherlands in order to test the study's hypotheses and address its central question. Relationships between several different variables will be compared to allow one to see whether certain correlations emerge, which could possibly uncover important predictors and causal factors of MASV. 
Table 1- Hungarian perceptions of MASV

\begin{tabular}{|c|c|c|c|c|}
\hline Statement. & Mean & SD & Median & Trimmed \\
\hline A woman must always obey her husband. & 73.74 & 30.25 & 87.5 & 78.55 \\
\hline Homosexuality is morally acceptable. & 27.27 & 30.59 & 12 & 22.23 \\
\hline $\begin{array}{l}\text { People should be free to choose their religion } \\
\text { and practice it freely. }\end{array}$ & 51.26 & 36.01 & 50 & 51.45 \\
\hline $\begin{array}{l}\text { One can justify killing a family member if } \\
\text { they have committed adultery or had non- } \\
\text { marital sex. }\end{array}$ & 57.75 & 34.13 & 59.5 & 59.31 \\
\hline Abortion should be illegal. & 51.96 & 35.60 & 50 & 52.25 \\
\hline $\begin{array}{l}\text { Authoritarian governments are more } \\
\text { effective than democratic ones in times of } \\
\text { difficulty. }\end{array}$ & 53.54 & 32.12 & 51 & 54.13 \\
\hline $\begin{array}{l}\text { Attacks on civilians are justifiable if they are } \\
\text { in defence of Islam. }\end{array}$ & 61.01 & 34.34 & 66 & 63.27 \\
\hline
\end{tabular}

Table 2 - Dutch perceptions of MASV

\begin{tabular}{|c|c|c|c|c|}
\hline Question & Mean & SD & Median & Trimmed \\
\hline A woman must always obey her husband. & 62.32 & 29.64 & 70 & 64.88 \\
\hline Homosexuality is morally acceptable. & $25 \cdot 35$ & 29.52 & 11 & 19.86 \\
\hline $\begin{array}{l}\text { People should be free to choose their religion } \\
\text { and practice it freely. }\end{array}$ & 52.04 & 32.86 & 51 & 52.19 \\
\hline $\begin{array}{l}\text { One can justify killing a family member if } \\
\text { they have committed adultery or had non- } \\
\text { marital sex. }\end{array}$ & 43.66 & 33.04 & 40 & 42.02 \\
\hline Abortion should be illegal. & 53.27 & 34.17 & 57.5 & 53.98 \\
\hline $\begin{array}{l}\text { Authoritarian governments are more } \\
\text { effective than democratic ones in times of } \\
\text { difficulty. }\end{array}$ & 46.4 & 30.58 & 50 & 45.63 \\
\hline $\begin{array}{l}\text { Attacks on civilians are justifiable if they are } \\
\text { in defence of Islam. }\end{array}$ & 44.02 & 33.45 & 41 & 42.57 \\
\hline
\end{tabular}




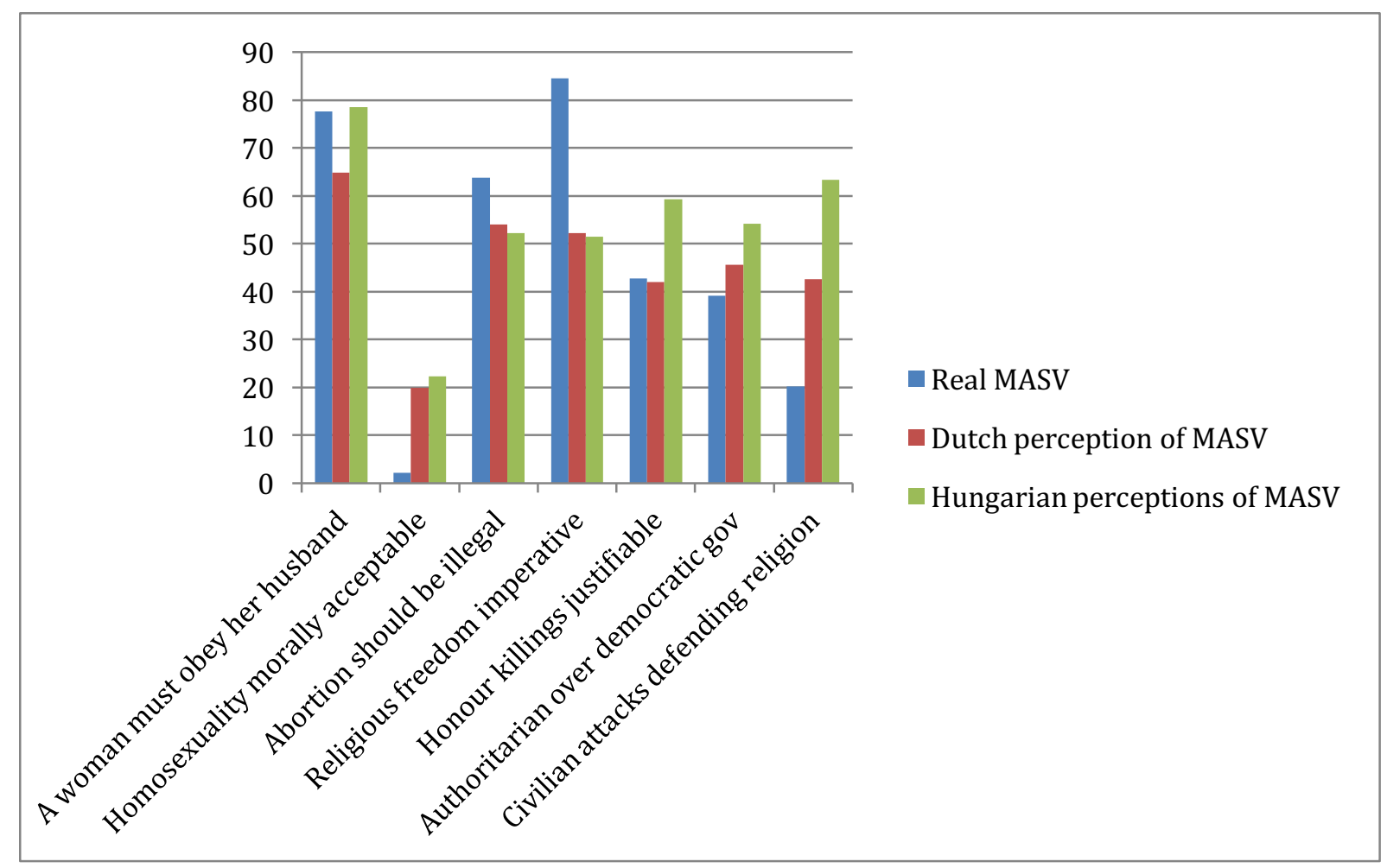

\section{Figure 1- Real MASV vs. Dutch and Hungarian perceptions}

NB: The figures used for both Hungarian and Dutch perceptions of MASV in Column graph 1 are obtained from the 'trimmed' column in tables 1 and 3 . The trimmed readings take the mean score of a revised results set that ignores the lowest and highest $5 \%$ of the data, thus removing outliers.

\section{Mean difference between perceptions of MASV and Real MASV:}

- Hungary - 18.81

- The Netherlands - 14.74

Total perceptions of MASV extremity:

- Hungary - 433.83

- The Netherlands - 379.03 


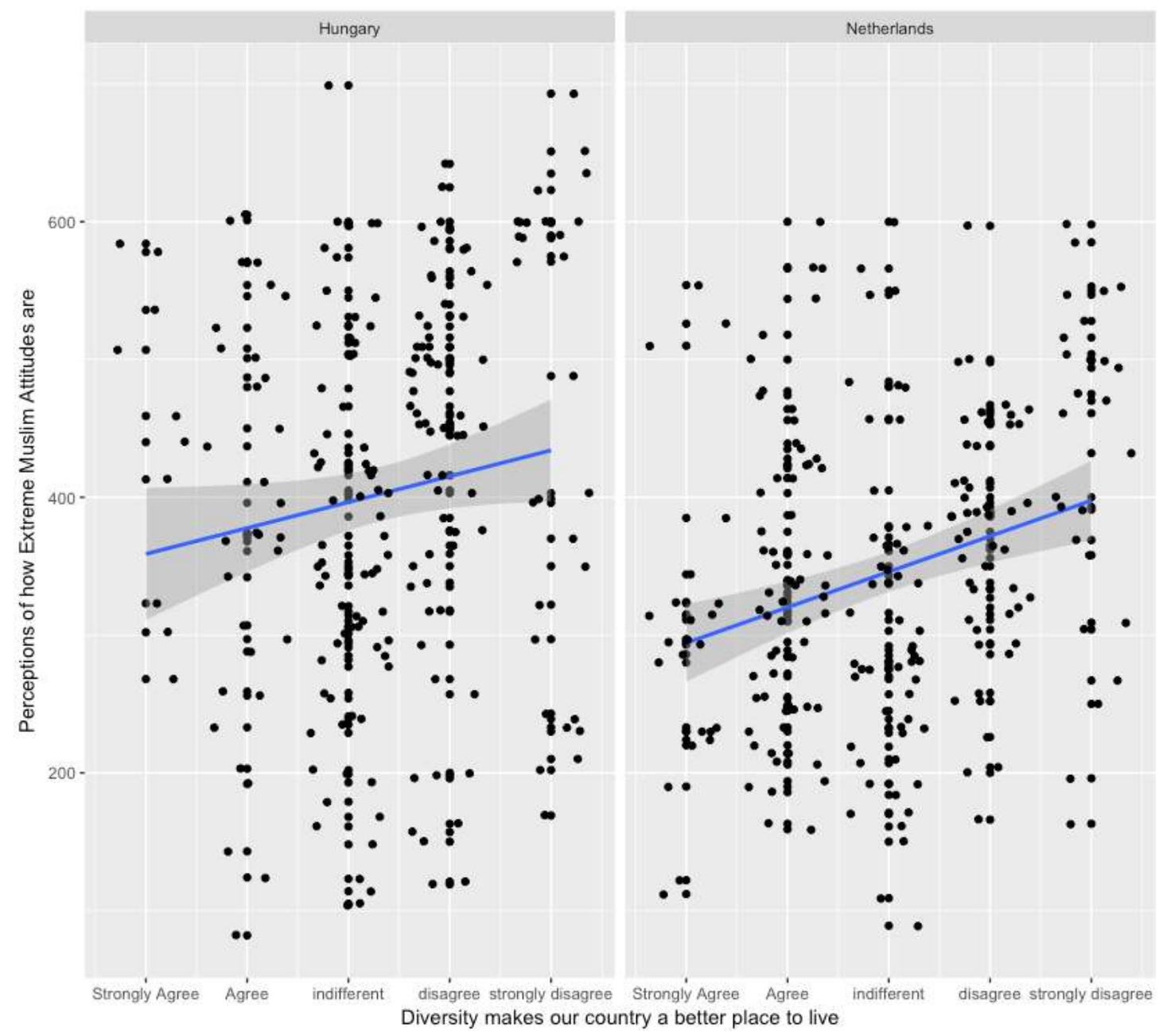

Figure 2- Relationship between attitudes to diversity and perceptions of MASV extremity

Correlation:

Hungary: $(r=0.1169)$, The Netherlands: $(r=0.2576)$. 


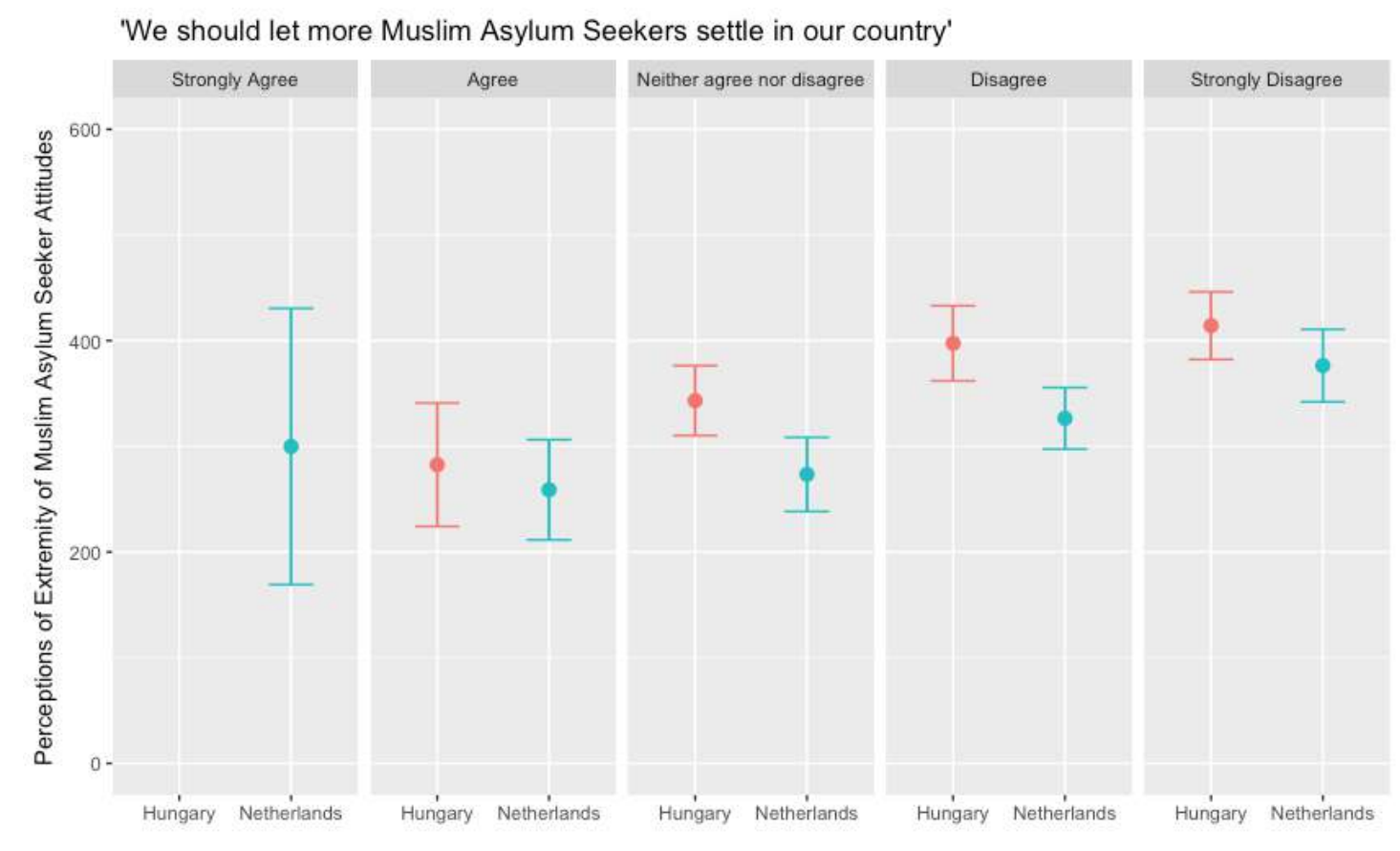

Figure 3- Relationship between attitudes toward MAS settlement and perceptions of MASV extremity

Correlation:

Hungary $(\mathrm{r}=0.305)$, The Netherlands $(\mathrm{r}=0.287)$. 


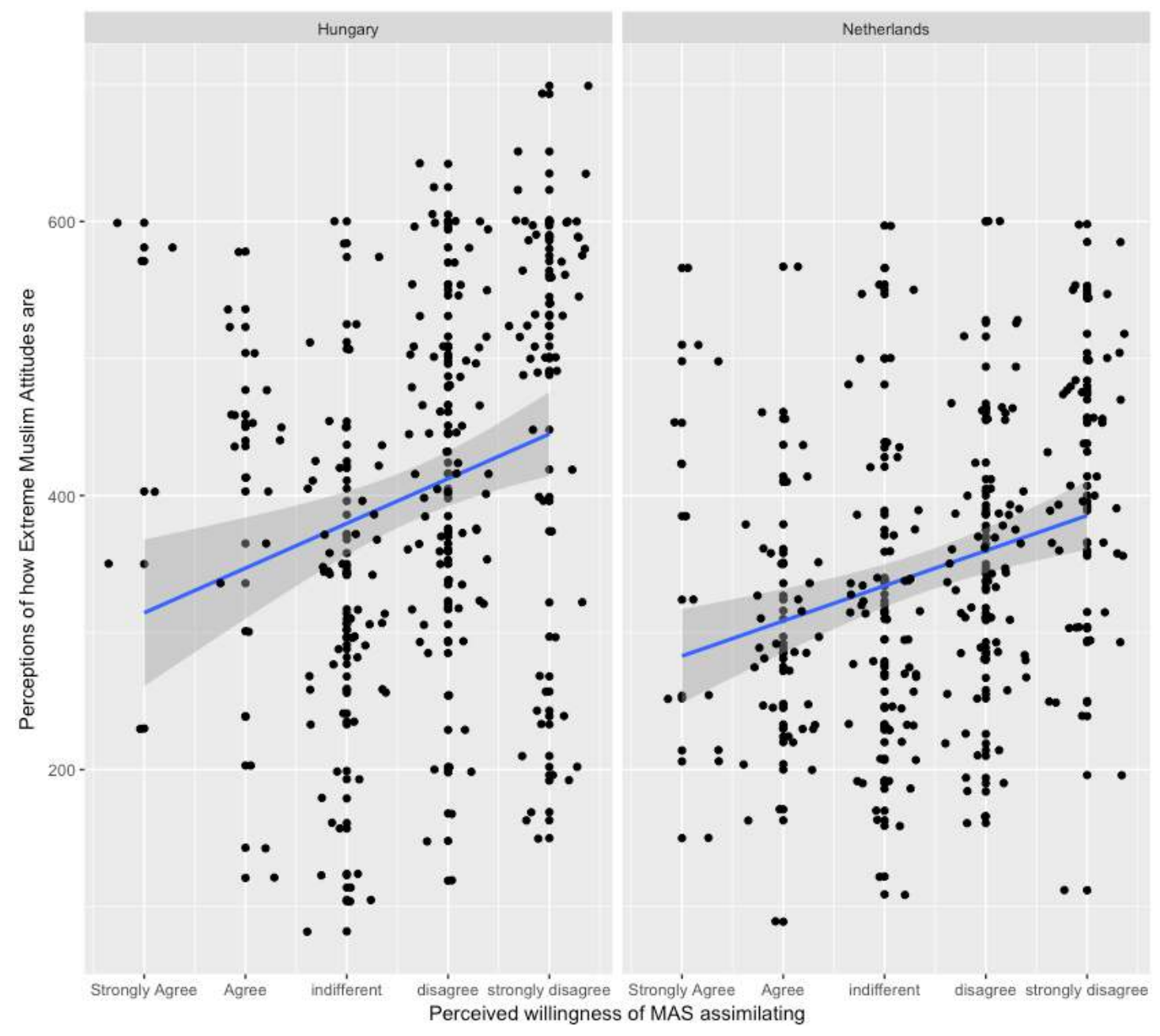

Figure 4- Relationship between WTA and perceptions of MASV extremity Correlation:

Netherlands $r=0.31$, Hungary $r=0.19$ 

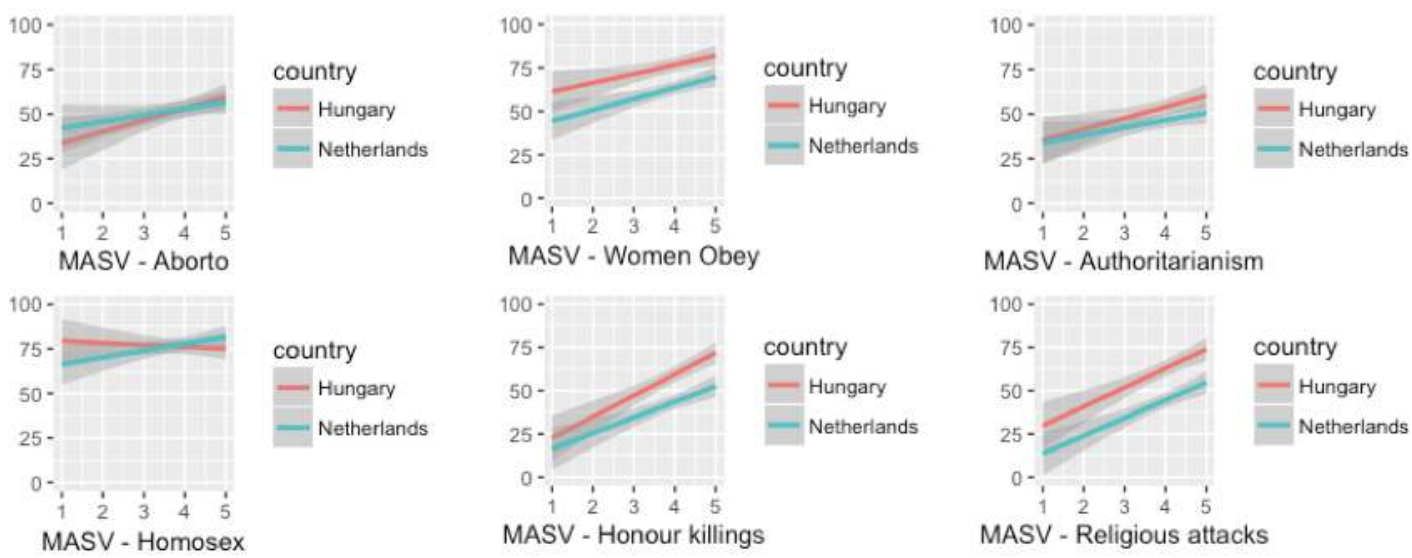

MASV - Authoritarianism
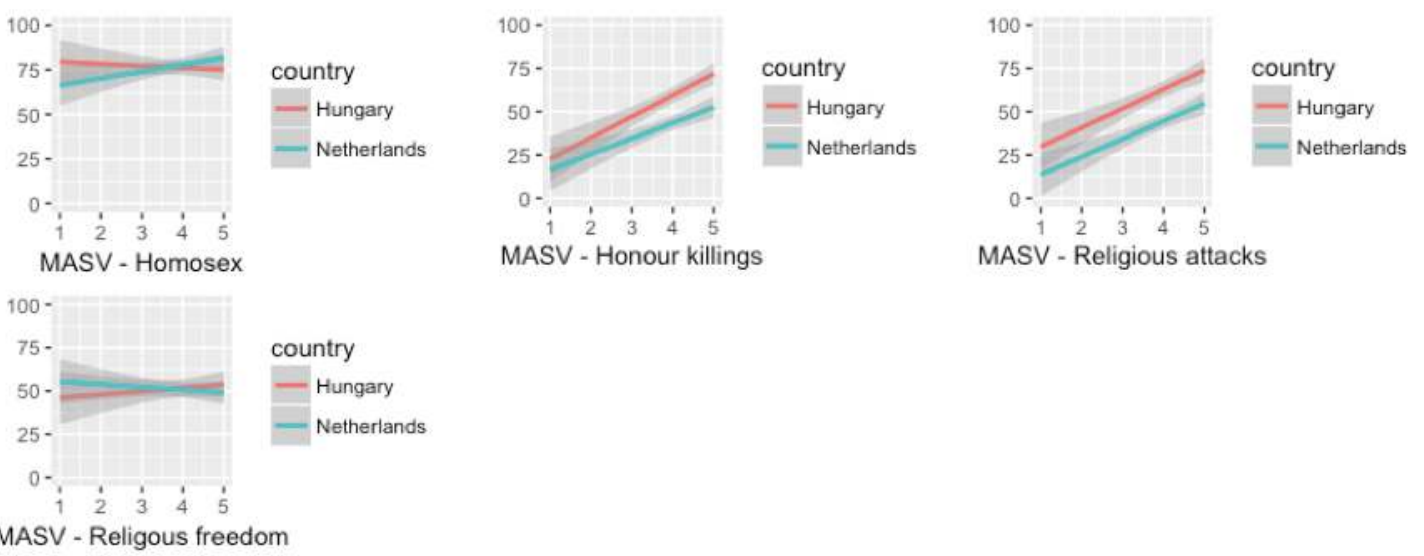

MASV - Religious attacks

\section{Figure 5- Relationship between perceptions of MASV extremity on individual questions and attitudes towards letting more MAS settle in one's country}

NB: $x$-axis= 'We should let more MAS settle in our country' ( $1=$ strongly agree, $2=$ agree, $3=$ neither agree nor disagree, 4 =disagree, 5 =strongly disagree). Aborto = 'Abortion should be illegal', Homosex= 'Homosexuality is morally acceptable.' Religious Freedom = 'People should be free to choose their religion and practice it freely,' Women Obey= 'A woman must always obey her husband,' Honour Killings= 'One can justify killing a family member if they have committed adultery or had not marital sex,' Authoritarianism= 'Authoritarian governments are more effective than democratic ones in times of difficulty,' Religious Attacks= 'Attacks on civilians are justifiable if they are in defence of Islam.'

\section{Why Hungarians believe they shouldn't allow more MAS to settle in their country}

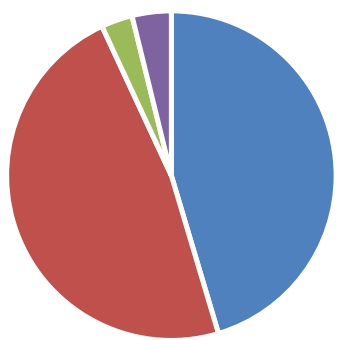

\footnotetext{
- They bring Violence and Terrorism

- Their values are incompatible with those we uphold in Hungary

- They're a burden to our Economy and Welfare System

- Other
}

\section{Figure 6}




\section{Why Dutch people believe their country shouldn't} allow more MAS to settle in The Netherlands.

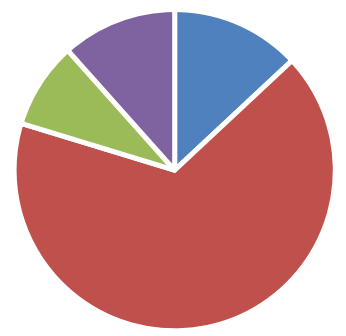

- They bring Violence and Terrorism

- Theirvalues are incompatible with those we uphold in The Netherlands

- They're a burden to our Economy and Welfare System

- Other

\section{Figure 7}

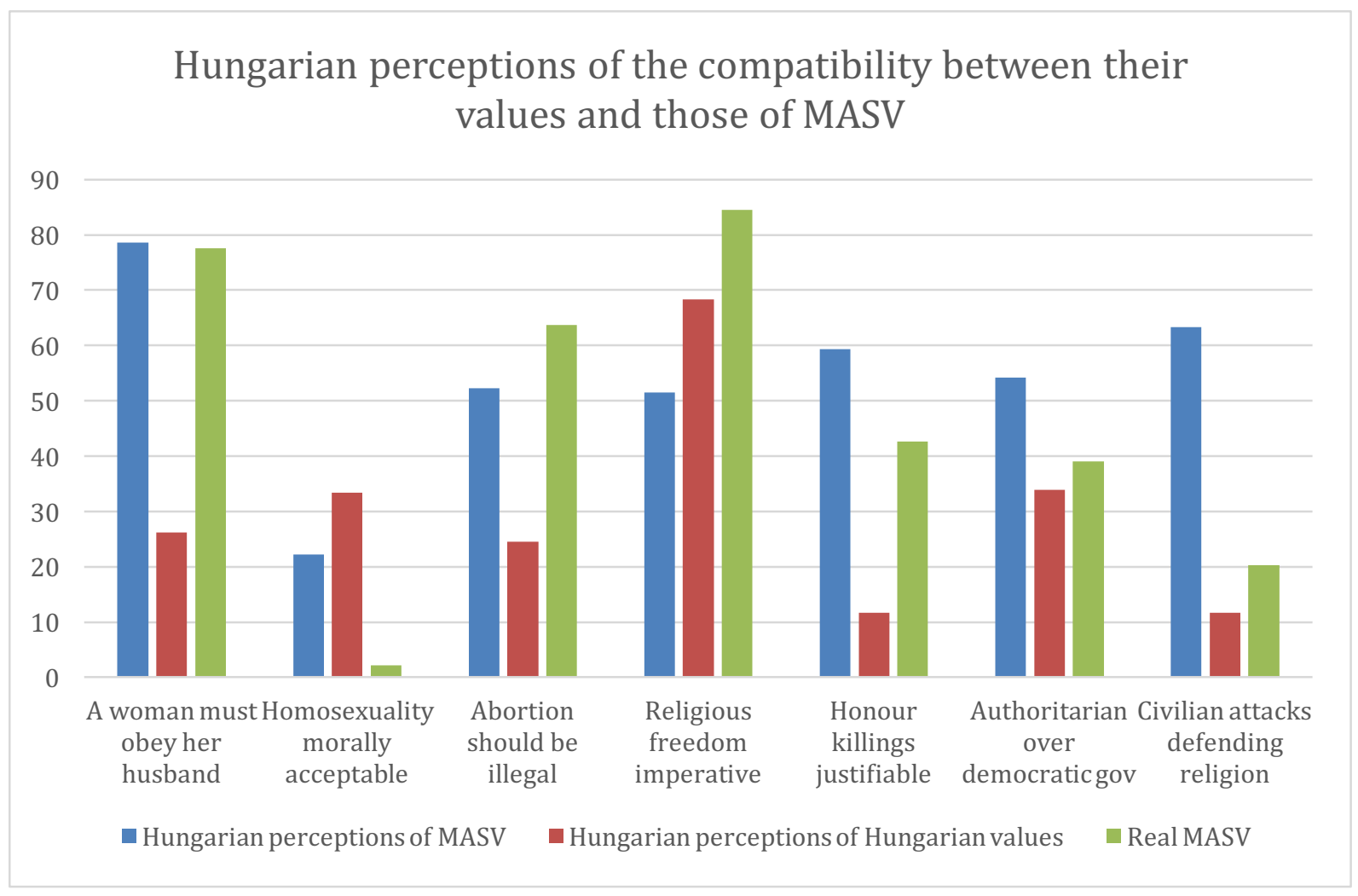

Figure 8 


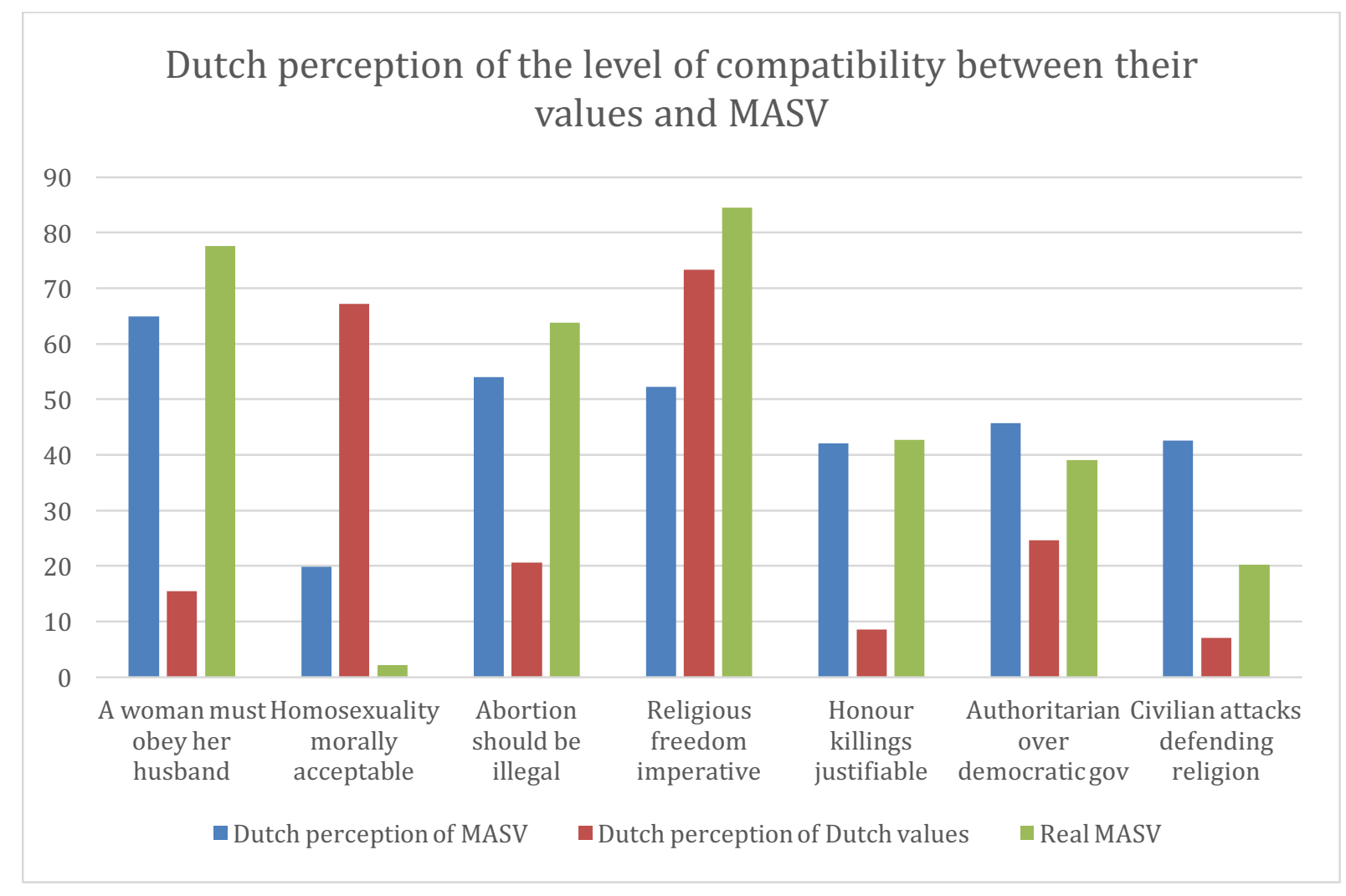

Figure 9

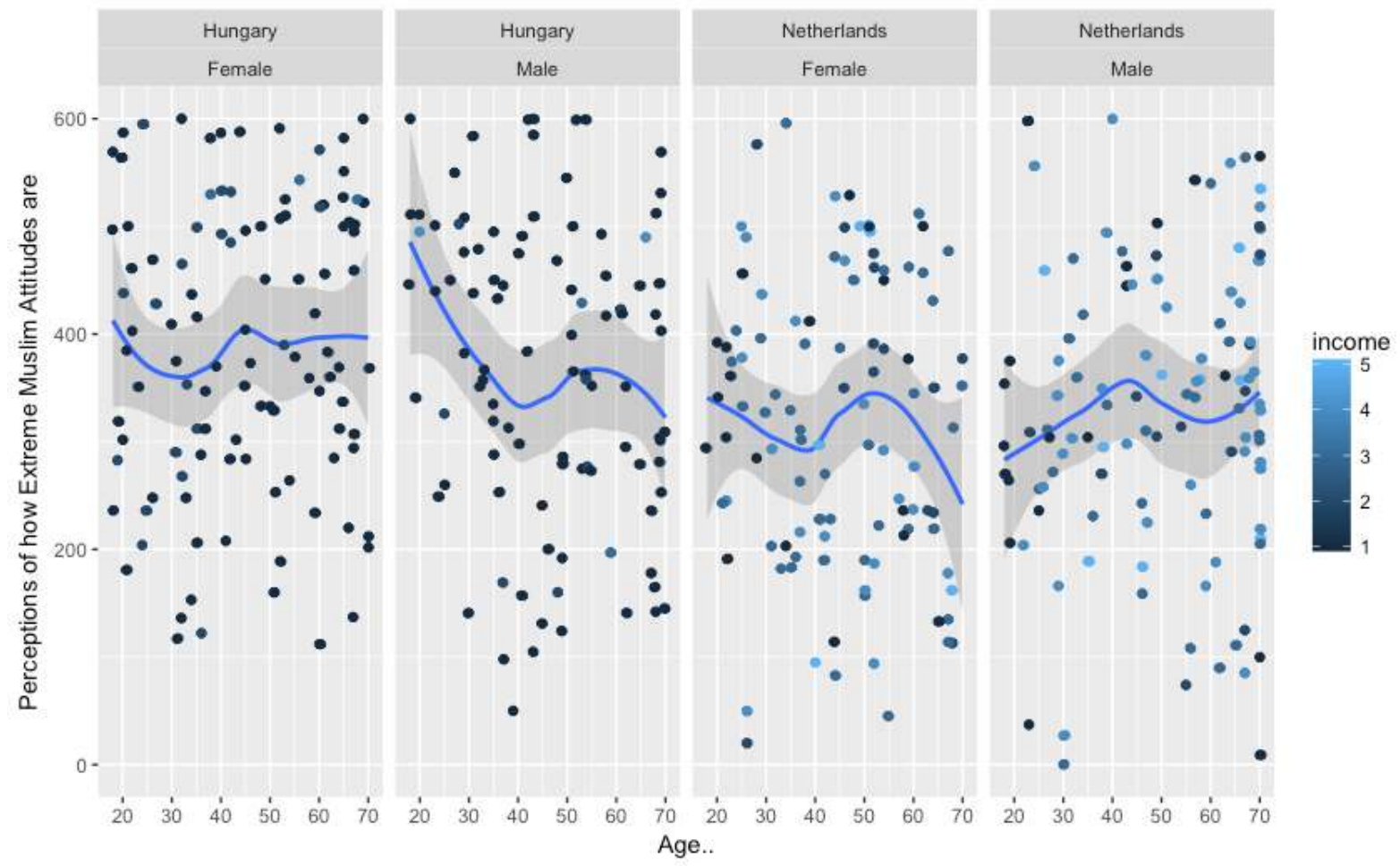

Figure 10 - Effects of age, gender and income on perceptions of MASV extremity 


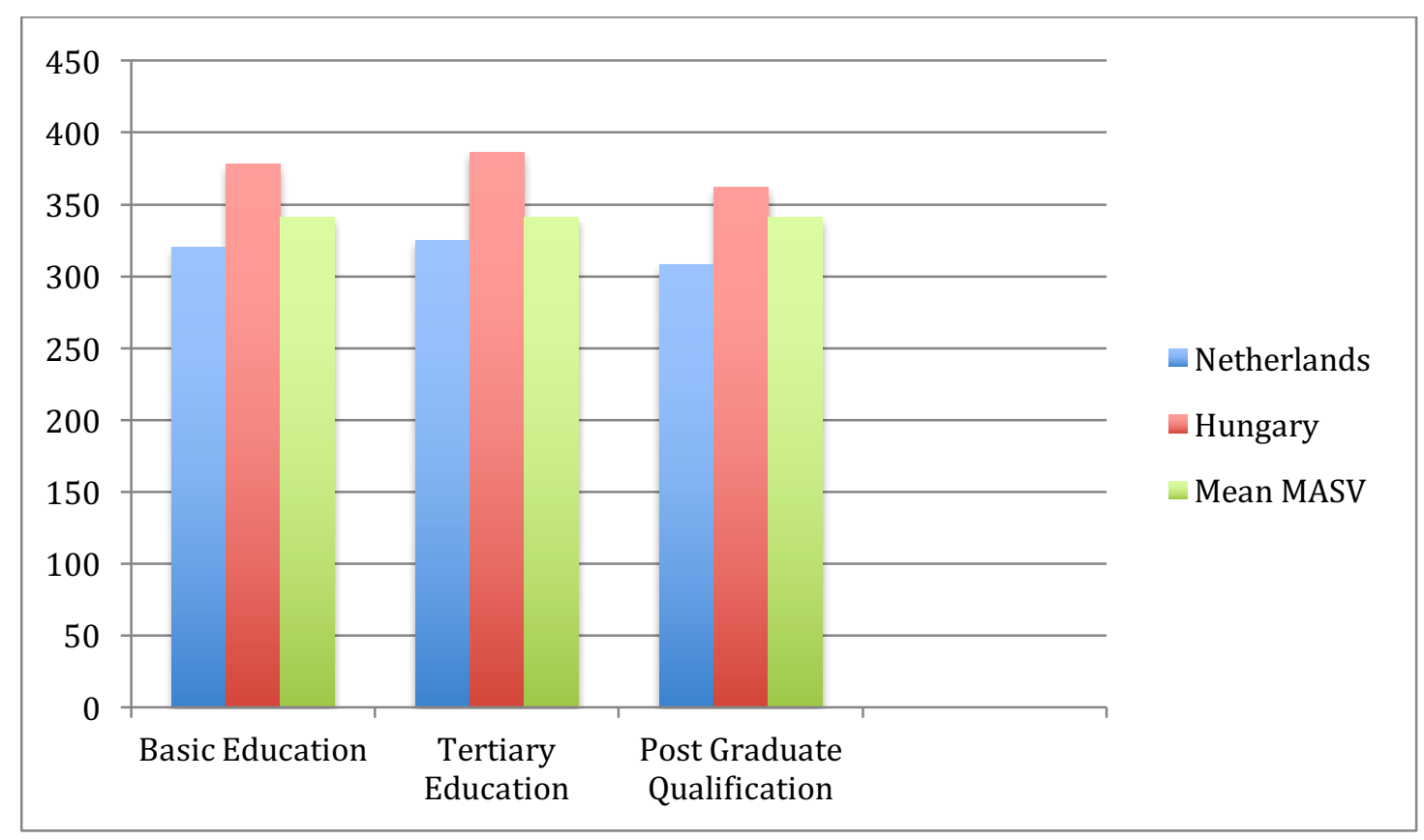

Figure 11- Effect of education level on perceptions of MASV

NB: Basic Education refers to completion of primary school only or primary school and secondary school.

\section{Discussion}

Figure 1 reveals the differences between Hungarian and Dutch perceptions of MASV and mean MASV scores across all seven topics of the BPV. Hungarian perceptions of MASV were less accurate than Dutch perceptions across all topics except on the question of whether a woman should obey her husband or not. The mean difference between their respective perceptions and the real MASV for each topic was 18.81 for Hungary and $\mathbf{1 4 . 7 4}$ for The Netherlands. Dutch participants tended to underestimate the extremity of MASV (four out of the seven questions), whereas Hungarians opted for a largely negative view of MASV, overestimating their extremity on five out of the seven topics. Moreover, Hungarians perceived MASV to be more extreme than Dutch people on five out of the seven topics, with homosexuality and abortion being the exceptions. In figure 2, one observes the correlation between negative attitudes towards diversity and increased perceptions of MAS extremity in the Netherlands $(\mathrm{r}=0.2576)$. Here it appears that when Dutch people perceive Total MASV extremity to be above 350, they also harbour negative views towards diversity. In the Hungarian case however there is a lower correlation $(\mathrm{r}=0.1169)$, which suggests that a Hungarian's attitudes toward diversity (ATD) has less of an impact upon their perceptions of MASV extremity. In figure 3 there appears to be a correlation in both Dutch and Hungarian views on letting more MAS settle (LMS) in their home country and perceptions of MASV extremity (Hungary $r=0.305$, The Netherlands $r=0.287$ ). Similarly, one observes a strong correlation between MASV extremity and the perceived willingness of MAS to assimilate with national customs and traditions (WTA) in both countries (figure 4). All comparisons here attempted to demonstrate the consequences that perceptions of MASV can have on other issues important to immigration policy and to see whether useful predictors of MASV perceptions can be identified. It appears as though ATD, LMS and the WTA were all affected by one's perception of MASV extremity. This would indicate that immigration policy preferences are associated with 
perceptions of MASV extremity. Conversely, these three variables could also be good predictors of perceptions of MASV extremity in other EU countries. The results for these graphs however, don't explain the reasons behind the elevated perceptions of MASV extremity among the Hungarian population vis-à-vis The Netherlands.

In an attempt to discover what these causal factors might have been, an analysis of both countries' perceptions of each separate issue in the BPV was conducted. Figure 5 shows the effect that each of these issues has on LMS, which I regarded as the variable most likely to reflect immigration policy preferences in the ERC context. The relatively flat lines that one observes in religious freedom, homosexuality, abortion and authoritarianism indicate that one's perception of MASV regarding these topics is relatively insignificant in influencing their views on MAS settlement. Conversely, the steep incline visible in both the honour killings and religious attacks issues indicates that these are key determinants of views on whether governments should allow more MAS to settle. Moreover, there is a difference of roughly 50 points in Hungarian perceptions of MAS support for religious attacks and honour killings between those who strongly agree that more MAS should be able to settle in Hungary and those that strongly disagree with the statement. This difference is significantly less in the Dutch case, indicating that fears of violence and terrorism play a smaller role in determining their views on MAS settlement. Finally, the fact that perceptions about homosexuality and women having to obey their husbands were the only two variables that generated a wider difference of views about MAS settlement among Dutch people compared to Hungarians suggests something interesting. Despite the incline not being as steep in either graph as it is in the two violence topics, it indicates that Dutch people are perhaps more concerned about the social value incompatibilities with MAS than Hungarians, whereas Hungarians appear to be considerably more concerned about MAS violence and terrorism than the Dutch.

Two thirds of Dutch people who believe their government should stop allowing MAS to settle in their country consider the value incompatibility aspect to be the main reason behind that decision (figure 7). This differs from the views of the same group of Hungarians, who are evenly divided in their reasoning between value incompatibility and the threat of violence and terrorism (figure 6). However, considering that Hungarians regarded the greatest value discrepancy of the BPV to exist in both killing related questions (figure 1), it is reasonable to assume that those Hungarians who view violence and terrorism as the main threat of MAS would also consider the value incompatibility to be a major reason behind denying MAS settlement in Hungary and vice versa. These findings appear to be consistent with the literature, where I found more evidence to suggest that perceived cultural fears would be better predictors of anti immigration sentiments than perceived economic fears.

Finally, figure 10 indicates that my assessment of the literature was accurate in regarding economic fears of immigration as insignificant. LMCT and FBT held that those with lower incomes would exhibit higher levels of resentment toward MAS given the latter would represent a threat to a native citizen's access to scare resources. The results presented in figure 10 suggest that income levels are poor predictors of MASV perceptions. The only interesting finding from this graph is that Hungarian males appear to excessively overestimate MASV vis-à-vis all other participants. Additionally, results from both countries do not appear to validate my hypothesis that the attainment of higher education would mitigate the tendency to overestimate MASV extremity. 


\section{Conclusion}

This study aimed to assess the significance of European perceptions of MASV in national immigration regimes. The literature had indicated that there was more reason to believe that fears of identity loss and value incompatibility were better predictors of immigration preferences than economic factors. Given the media salience of MAS in recent times and the ability of right-wing populists to construct sensational narratives that exploit culture-based fears, I decided to measure just how greatly this combination had falsified European views of MASV. Although policies adopted by both Dutch and Hungarian governments in this field weren't analysed, the study discovered a correlation between three variables significant to immigration preferences and perceptions of MASV extremity. Thus, it appears that European perceptions of MASV are good predictors of national immigration policies.

The second objective of this study was to measure the inaccuracy of these perceptions. Both Hungary and the Netherlands held largely inaccurate perceptions of MASV. Whereas Dutch people tended to underestimate the extremity of MASV, Hungarians overestimated their extremity. The former's imprecise account could be problematic in Dutch society's stance on gender equality with their perceptions of MAS acceptance of homosexuality and female obedience far from actual MASV on these issues. On the other hand, Hungarians overestimated MASV regarding honour killings, religious attacks and authoritarian governance preferences by a considerable margin. This could be interpreted as a sign that Hungarians believe MAS bring violence and terrorism.

Finally, the study wasn't able to identify potential causes of these inaccuracies with both income levels and education failing to display any relationship with perceptions of MASV. However, given my first hypothesis appeared to confirm the literature's concerns with identity exclusionism and the interaction between right wing populism and media organisations, it would be worthwhile to investigate the precise relationship between the media's portrayal of MAS and perceptions of MASV across several EU countries. Additionally, more research should be undertaken that analyses the influence of national education systems on the formation of perceptions of MASV.

\section{References}

Aberson, Cristopher \& Sarah Haag. (2007) Contact, perspective taking, and anxiety as predictors of stereotype endorsement, explicit attitudes, and implicit attitudes. Group Processes and Intergroup Relations, Vol. 10, pp. 179-201.

Akkerman, Tjitske. (2005) 'Anti-Immigration parties and the defence of liberal values: The exceptional case of the List Pim Fortuyn,' Journal of Political Ideologies, Vol. 10, Issue 3.

Akkerman, Tjitske. (2012) 'Comparing Radical Right Parties in Government: Immigration and Integration Policies in Nine Countries (1996-2010),' West European Politics, Vol. 35, Issue 3.

Al Ramiah, Ananthi, Miles, Hewstone \& Katharina Schmid. (2011) Intergroup difference and harmony: The role of intergroup contact. In Singh, P., Bain, P., Leong, C., Misra, G., Ohtsubo, Y. (Eds.), Individual, group and cultural processes in changing 
societies. Progress in Asian Social Psychology (Series 8), pp. 3-22. Delhi: University Press.

Allport, Gordon. (1954) The Nature of Prejudice. Cambridge/Reading, MA: AddisonWesley.

Banting, Keith \& William Kymlicka. (2006) Multiculturalism and the Welfare Stat: Recognition and Redistribution in Democracies. Oxford: Oxford University Press.

Bell, James \& Luis Lugo. (2013) 'The World’s Muslims: Religion, Politics and Society', Pew Research Center.

Berman, Sheri. (2006) The Primacy of Politics: Social Democracy and the Making of Europe's Twentieth Century. Cambridge: Cambridge University Press.

Berry, Mike, Inaki Garcia-Blanco \& Kerry Moore. (2015) 'Press coverage of the Refugee and Migrant Crisis in the EU: A Content Analysis of Five European Countries,' Report prepared for the United Nations High Commission for Refugees, Cardiff School of Journalism, Media and Cultural Studies.

Betz, Hans-George. (1993) 'The new politics of resentment: Radical right wing populist parties in Western Europe', Comparative Politics, Vol. 25, Issue 4.

Bilodeau, Antoine \& Nada Fadol. (2011) 'The roots of contemporary attitudes toward immigration in Australia: contextual and individual-level influences,' Ethnic and Racial Studies, Vol.34, Issue 6.

Bjerre, Liv, Marc Helbling, Friederike Römer \& Malisa Zobel. (2016) 'The Immigration Policies in Comparison (IMPIC) Dataset: Technical Report, Berlin Social Science Center

Blalock, Hubert. (1967) Toward a Theory of Minority Group Relations, New York: John Wiley \& Sons.

Blascovich, Jim, Wendy Mendes, Sarah Hunter, Brian Lickel \& Neneh Kowai-Bell. (2001) 'Perceiver threat in social interactions with stigmatized others,' Journal of Personality and Social Psychology, 80, 253-267

Borjas, George, Richard Freeman \& Lawrence Katz. (1996) 'Searching for the Effect of Immigration on the Labor Market,' NBER Working Paper No. 5454, NBER Program.

Brady, David \& Ryan Finnigan. (2014) 'Does Immigration Undermine Public Support for Social Policy,'American Sociological Review, Vol. 79, Issue 1.

Brown, Rupert. (2000) 'Social Identity Theory: Past Achievements, Current Problems and Future Challenges', European Journal of Social Psychology, Vol. 30, Issue 6, Pages 745-778.

Calhoun, Craig. (2002) 'Imagining Solidarity: Cosmopolitanism, Constituional Patriotism, and the Public Sphere.' Public Culture, Vol. 14, Issue 1.

Caspi, Avshalom. (1984) 'Contact Hypothesis and Inter-Age Attitudes: A Field Study of Cross Age Contact,' Social Psychology Quarterly, Vol. 47, No. 1 
Cavaille, Charlotte \& John Marshall. (2017) 'Education and Anti-Immigration Attitudes: Evidence from Compulsory Schooling Reforms Across Western Europe,' Harvard University, viewed from https://scholar.harvard.edu/files/jmarshall¿files/education_and_anti-immigration_attitudes_o.pdf

Connor, Phillip. (2016) "Number of Refugees to Europe surges to record 1.3 Million in 2015," Pew Research Center - Global Attitudes and Trends.

Dancygier, Rafaela \& Michael Donnelly. (2012) 'Sectoral Economies, Economic Contexts, and attitudes toward Immigration,' The Journal of Politics, Vol 75, Issue 1, pp17-35

Dekker, Rianne \& Peter Scholten, (2017) 'Framing the Immigration Policy Agenda: A Qualitative Comparative Analysis of Media Effects on Dutch Immigration Policies,' The International Journal of Press/Politics, Vol. 22, Issue 2.

Facchini, Giovanni \& Anna Mayda. (2009) 'Does the Welfares State Affect Individual Attitudes toward Immigrants? Evidence across Countries.' Review of Economics and Statistics 91 (2): 295-314

Hackett, Conrad. (2016) "5 Facts about the Muslim Population in Europe," Pew Research Center- Fact Tank.

Hainmueller, Jens \& Michael Hiscox. (2007) Educated Preferences: Explaining Attitudes toward immigration in Europe. International Migration Review, Vol. 30, No. 2.

Hainmueller, Jens, Michael Hiscox. (2010) 'Attitudes toward Highly Skilled and Lowskilled Immigration: Evidence from a Survey Experiment,' American Political Science Review, Vol. 104, No.1

Hanson, Gordon. (2005) Why Does Immigration Divide America? Washington, DC: Institute for International Economics.

Hanson, Gordon, Kenneth Scheve \& Matthew Slaughter. (2007) 'Public Finance and Individual Preferences over Globalisation Strategies.' Economics and Politics 19 (1): 1-33

Huddy, Leonie. (2001) 'From Social to Political Identity: A Critical Examination of Social Identity Theory', Political Psychology, Vol. 22, Issue 1.

Ipsos MORI (2016) 'Perceptions are not reality: what the world gets wrong,' Ipsos MORI: Game Changers, viewed from https://www.ipsos.com/ipsos-mori/enuk/perceptions-are-not-reality-what-world-gets-wrong

Iyer, Aarti, Jolanda Jetten. (2011) 'What's left behind: Identity continuity moderates the effect of nostalgia on well-being and life choices,' Journal of Personality and Social Psychology, Vol.101, Issue 1.

Jacobs, Laura, Cecil Meeusen \& Leen D’haenens,. (2016) 'News coverage and attitudes on immigration,' European Journal of Communication, Vol.3, Issue 6, pp. 642-660. 
Joppke, Christian. (2010) Citizenship and Immigration. Oxford: Polity.

Kesler, Christel \& Irene Bloemraad. (2010) 'Does Immigration Erode Social Capital? The Conditional Effects of Immigratio-Generated Diversity on Trust, Membership, and Participation across 19 Countries, 1981-2000.' Canadian Journal of Political Science, Vol. 43, Issue 2, 319-47

Kessler, Alan. (2001) Immigration, Economic Insecurity and the 'Ambivalent' American Public. Working Paper. La Jolla, CA: Center for Comparatove Immigration Studies.

Kinder, Donald \& David Sears. (1981) 'Prejudice and politics: Symbolic racism versus racial threats to the good life,' Personality and Social Psychology Review, Vol. 10, pp. 336-353.

Koning, Edward. (2013) 'Selective Solidarity: The politics of immigrants' social rights in Western welfare states,' (Doctoral dissertation). Kingston, Ontario, Canada: Retrieved from Queen's University.

Kymlicka, William. (2015) 'Solidarity in diverse societies: beyond neoliberal multiculturalism and welfare chauvinism. Comparative Migration Studies, Vol. 3 , Issue 4, pp. 301-334.

Lucassen, Geertje \& Marcel Lubbers. (2012) 'Who Fears What? Explaining Far-RightWing Preference in Europe by Distinguishing Perceived Cultural and Economic Ethnic Threats,' Comparative Political Studies, Vol. 45, Issue 5.

Markaki, Yvonni \& Simonetta Longhi. (2013) 'What determines attitudes to immigration in European countries? An analysis at the regional level,' Migration Studies, Vol. 1, Issue 3.

Mayda, Anna Maria (2006) 'Who is against immigration? A cross-country investigation of individual attitudes toward immigrants,' Review of Economics and Statistics, Vol 88, Issue 3.

McConahay, John. (1982) 'Self-interest versus racial attitudes as correlates of antibusing attitudes in Louisville: Is it the buses or the blacks?' Personality and Social Psychology Review, Vol 10, pp. 336-353.

Mols, Frank. (2012) What makes a frame persuasive? Lessons from social identity theory. Evidence \& Policy, Vol. 8, Issue 3, pp. 329-345.

Mols, Frank \& Jolanda Jetten. (2014) 'No guts, no glory: How framing the collective past paves the way for anti-immigrant sentiments,' International Journal of Intercultural Relations, Volume 43, Part A.

Mudde, Cas. (2007) Populist radical right parties in Europe. Cambridge, UK: Cambridge University Press.

Olzak, Susan. (1994) The Dynamics of Ethnic Competition and Conflict, Stanford, CA: Stanford University Press. 
Pettigrew, Thomas. (1998) 'Intergroup contact theory,' Annual review of psychology, Vol. 49, Issue 1, pp. 65-85.

Pettigrew, Thomas \& Linda Tropp. (2006) 'A meta-analytic test of intergroup contact theory, Journal of Personality and Social Psychology, Vol. 90, Issue 5

Ponce, Aaron. (2017) 'Gender and Anti-immigrant Attitudes in Europe,' Socius: Sociological Research in a Dynamic World, Vol. 3, pp.1-17

Quillian, Lincoln. (1995) 'Prejudice as a response to perceived group threat:

Population composition and anti-immigrant and racial prejudice in Europe,' American Sociology Review, Vol. 6o, Issue 4, pp. 586-611.

Reicher, Stephen \& Nick Hopkins. (2001) Self and Nation, Sage, London, UK.

Sager, Alex. (2016) 'Methodological Nationalism, Migration and Political Theory,' Political Studies, Vol. 64, Issue 1.

Scheepers, Peer, Mérove Gijsberts \& Marcel Coenders. (2002) 'Ethnic exclusionism in European countries. Public opposition to civil rights for legal migrants as a response to perceived ethnic threat,' European Sociological Review, Vol. 18: 17-34

Scheve, Kenneth \& Matthew Slaughter. (2001) 'Labour Market Competition and Individual Preferences Over Immigration Policy,' The Review of Economics and Statistics, Vol. 83, Issue 1.

Schlueter, Elmar \& Peer Scheepers. (2010) 'The relationship between outgroup size and anti-outgroup attitudes: A theoretical synthesis and empirical test of group threat- and intergroup contact theory,' Social Science Research, Vol. 39, pp. 285-95.

Schmitt, Carl. (1996) The Concept of the Political. Chicago: University of Chicago Press.

Schneider, Silke. (2008) 'Anti-immigrant attitudes in Europe: Outgroup size and perceived ethnic threat,' European Sociological Review, Vol. 24, pp. 53-67.

Sides, John \& Jack Citrin. (2007) 'European Opinion About Immigration: The Role of Identities, Interests and Information,' British Journal of Political Science, Vol. 37 Issue 3, pp. 477-504.

Sniderman, Paul \& Louk Hagendoorn. (2007) When Ways of Life Collide: Multiculturalism and Its Discontents in the Netherlands. Princeton: Princeton University Press.

Sniderman, Paul, Louk Hagendoorn \& Markus Prior. (2004) 'Predisposing Factors and Situational Triggers: Exclusionary Reactions to Immigrant Minorites', The American Political Science Review, Vol. 98, Issue 1

Swank, Duane \& Hans-George Betz. (2003) 'Globalization, the welfare state and right wing populism in Western Europe', Socio-Economic Review, Vol. 1, pp. 215-245 
Tajfel, Henri \& John Turner. (1979) 'An integrative theory of intergroup conflict'. In W. Austin \& S. Worchel. The social psychology of intergroup relations. Monterey, CA: Brooks/Cole. pp. 33-47.

Tebble, Adam. (2006) 'Exclusion for democracy,' Political Theory, Vol. 34, Issue 4, pp. 463-87

Van Setten, Menno, Scheepers, Peer \& Marcel Lubbers. (2017) 'Support for restrictive immigration policies in the European Union 2002-2013: the impact of economic strain and ethnic threat for vulnerable economic groups, European Societies, Vol. 19, Issue 4, pp. 440-465.

Vonofakou, Christiana, Miles Hewstone \& Alberto Voci. (2007) 'Contact with outgroup friends as a predictor of meta-attitudinal strength and accessibility of attitudes towards gay men.' Journal of Personality and Social Psychology, Vol. 92, pp. 804-820

West, Keon \& Joda Lloyd. (2017) 'The Role of Labelling and Bias in the Portrayals of Acts of 'Terrorism': Media Representations of Muslims vs Non-Muslims,' Journal of Muslim Minority Affairs, Vol 37, Issue 2, pp. 211-222 